\title{
Morpho-anatomical and morphometric studies of the floral structures of the distylous Oldenlandia salzmannii [Rubiaceae]
}

\author{
Mariela Nuñez Florentin ${ }^{\natural \star}$, Andrea Cabaña Fader ${ }^{1}$ and Ana Maria Gonzalez
}

Received: July 13, 2016

Accepted: October 6, 2016

\begin{abstract}
The genus Oldenlandia (Rubiaceae) has a conflicting generic delimitation, with representatives that show different floral syndromes. Oldenlandia salzmannii is a marshy herb that is widespread in South America. It is heterostylous, specifically distylous, and self-compatible. Recent molecular phylogenetic studies found that this species forms a clade that is isolated from the remaining described taxa of Oldenlandia. Information about the floral anatomy and reproductive biology of genera in the Spermacoceae tribe, particularly Oldenlandia, is insufficient, especially among the neotropical species. Accordingly, the present study aimed at contributing information on the reproductive biology of Oldenlandia salzmannii by analyzing its floral morpho-anatomy, morphometrics and phenology of both floral morphs. These analyses were conducted with natural, cultivated and fixed material using optical and scanning electron microscopes. Morphologically, the species is typically heterostylous with two floral morphs, long-styled and short-styled, the main difference being the indument of the corolla. The short-styled flowers have larger anthers and pollen grains. Morphometrics show a high degree of herkogamic reciprocity. The mature ovules have a hemitropous position, which is the first record of this position for the Spermacoceae tribe. This study represents the first comprehensive morphological study of Oldenlandia salzmannii.
\end{abstract}

Keywords: floral anatomy, heterostyly, Oldenlandia salzmannii, ovule development, Spermacoceae

\section{Introduction}

Heterostyly is a genetically controlled floral polymorphism in which plant populations are composed of two (distyly) or three (tristyly) morphs that differ reciprocally in the style and stamen lengths (Webb \& Lloyd 1986). Distyly presents long-styled flowers (LS) with a long style and short stamens, and short-styled flowers (SS) with a short style and long stamens. This reciprocal herkogamy is usually genetically linked with a diallelic, sporophytic self-incompatibility system (Ganders 1979), by which the only intermorph crossings are those that produce viable fruits and seeds. Moreover, heterostylous species may also present differences between the morphs in the ancillary characters, which are mostly related to the pollen and stigma features (Dulberger 1974; 1992; Ganders 1979). This floral polymorphism appears several times among angiosperms (Ganders 1979), the Rubiaceae family being the main taxon with the largest number of heterostylous species and genera.

\footnotetext{
${ }^{1}$ Instituto de Botánica del Nordeste (CONICET-UNNE), Sargento Cabral 2131, cc. 209, CP. 3400. Corrientes, Argentina

* Corresponding author: marielaflorentin22@gmail.com
} 
Bahadur (1968) and Ganders (1979) reported 416 distylous species in 91-92 genera of Rubiaceae.

One of the genera of Rubiaceae that has both heterostylous and homostylous species is Oldenlandia, which has recently been incorporated into the Spermacoceae tribe, based on molecular studies (Bremer 1996; Andersson \& Rova 1999). It is a conflicting taxon in its generic delimitation and together with the related genera, Hedyotis and Kohautia, they currently form an unresolved taxa complex called the "Hedyotis-Oldenlandia complex". According to Guo et al. (2013), the species of that complex are grouped in seven clades of predominantly paleotropical distribution, where the paleotropical species are separated from the neotropical species.

Oldenlandia salzmannii is a perennial herb with creeping stems 8-10 cm high, found in wet soils (Riveros et al. 1995). It is one of the best known distylous species of the genus in America because it is widespread in South America and introduced in North America and also because it is one of the few herbaceous species of the family that has a southern distribution, both in Argentina and Chile (Fosberg \& Terrel 1985; Terrell 1990; Bacigalupo 1999). In recent molecular phylogeny studies, this species forms a clade isolated from the rest of the described taxa in Oldenlandia (Neupane et al. 2015). In addition, according to Riveros et al. 1995, O. salzmannii is self-compatible which makes it even more interesting.

In the Spermacoceae tribe the studies of floral anatomy, vascularization and ovule development are isolated and scarce (Fagerlind 1937; Galati 1991; Toni \& Mariath 2004; 2008; Vaes et al. 2006). Moreover, in the HedyotisOldenlandia complex, palynological, embryological and anatomical studies are also scarce, mostly focusing on African and Asian species (Lewis 1964; 1965; Shivaramaiah \& Rajan 1972; Neupane et al. 2009). Oldenlandia salzmannii has only been treated taxonomically in regional flora and revision studies (Delprete et al. 2005; Terrel \& Robinson 2006; Delprete 2010). Therefore the information about the floral anatomy and reproductive biology in genera of the Spermacoceae tribe, and especially in Oldenlandia, is insufficient, and even more so in the neotropical species.

The present study aimed to contribute information about the reproductive biology of the taxon. For this purpose the following studies were performed (1) comparative morphology, anatomy and vascularization of both floral morphs, (2) ovule development, (3) comparative floral morphometry analysis of the morphs, and (4) floral phenology analysis.

\section{Materials and methods}

Flowers of Oldenlandia salzmannii (DC.) Benth. \& Hook. f. ex B.D. Jacks were collected from natural populations in Corrientes, Argentina. The present study is based on herbarium collections, field observation and material collected and fixed with formaldehyde, acetic acid and alcohol (FAA). Voucher specimens were deposited in the Carmen Cristóbal Herbarium (CTES) under accession numbers: ARGENTINA. Corrientes: La Cruz, private reserve, "Paraje Tres Cerros, "Nuñez Florentín et al. 141; San Cosme, private reserve "Las Lomas", Nuñez Florentín et al. 142; Concepción,

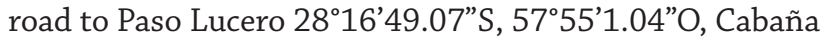
Fader 36; Concepción, Tabay, Arbo 265; Ituzaingó, Isla Apipé Grande, San Antonio Port, Krapovickas 23784; Mburucuyá, cañada Fragosa, Schwarz 8857; San Miguel, Ipacarapa lagoon, Schinini 34936.

\section{Floral morphometry}

Twenty flowers per morph were measured from one population in La Cruz. For measurements, corollas were slit longitudinally from just above the inferior ovary; the apex of the inferior ovary was the baseline for all measurements (Fig. 1). A digital caliper was used to measure: (1) stamen height, (2) anther length, (3) style-stigma height, (4) stigma length, (5) corolla length, (6) corolla tube length, (7) petal length. The difference (8) between style-stigma and stamen heights (reciprocal herkogamy) was calculated for each flower as the absolute value of stamen height less the style-stigma height. Each of these variables was compared between morphs using one-way ANOVA $(\alpha=0.001)$. The index of herkogamy (HK) was also calculated for both morphs, applying the following calculations:

$\mathrm{HK}_{\mathrm{sS}}$ : mean style-stigma length in S-morph/ mean stamen length in L-morph

$\mathrm{HK}_{\mathrm{LS}}$ : mean style-stigma length in L-morph/ mean stamen length in $\mathrm{S}$-flowers

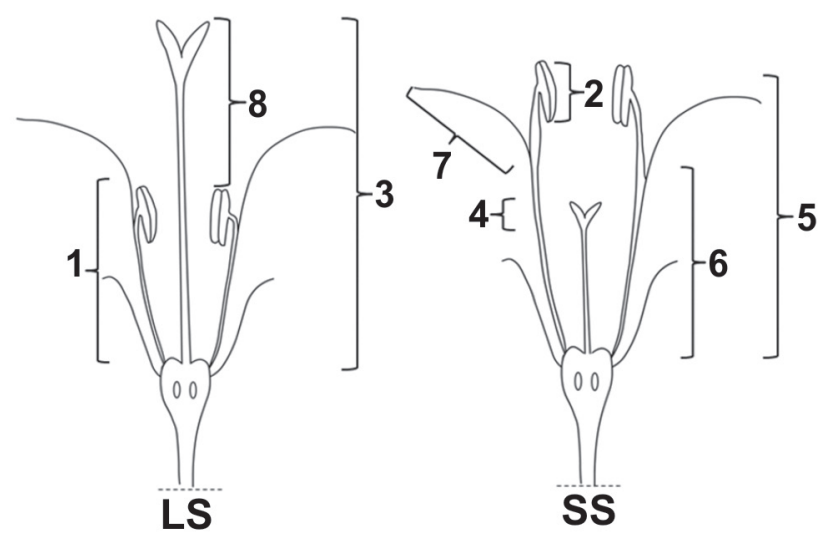

Figure 1. Long-styled (LS) and short-styled (SS) flowers of Oldenlandia salzmannii. Numerals correspond to the following measurements for both floral morphs: (1) stamen height, (2) anther length, (3) style-stigma height, (4) stigma length, (5) corolla length, (6) corolla tube length, (7) petal length, (8) difference between style-stigma and stamen height. 
Morpho-anatomical studies

For scanning electron microscope (SEM) studies, flowers were dehydrated using a graded series of ethanol solutions, dried at critical-point and sputter-coated with gold-palladium. Micrographs were obtained with a JEOL $5800 \mathrm{LV}$ scanning electron microscope operating at $20 \mathrm{kV}$.

For light microscopy (LM), fixed material of floral buds and open flowers were dehydrated by histological dehydration (Gonzalez \& Cristóbal 1997) and infiltrated in paraffin, according to Johansen (1940). The material was sectioned transversely and longitudinally $(12-15 \mu \mathrm{m}$ thickness for flowers at anthesis, and 8-10 $\mu \mathrm{m}$ thickness for floral buds) using a rotary microtome (Microm). Sections were stained in a safranin-astra blue combination (Luque et al. 1996) and mounted with synthetic Canada balsam (Biopur). The serial sections were examined under a Leica DMLB2 light microscope (LM) equipped with a digital camera (Canon Power Shot S50 AIAF). Observation of the corolla hairs was performed with clearing methods using sodium hypochlorite $50 \%$. Pollen grains were acetolyzed according to Erdtman (1966) and mounted in glycerine jelly for analysis under light microscope (LM). To determine the size of pollen grains, the equatorial diameter (E) and polar axis $(\mathrm{P})$ were measured on 20 pollen grains under $\mathrm{LM}$.

Measurements were taken of 10 different flowers based on SEM micrographs and of five flowers of the same population based on photographs of permanent slides using the program ImageJ (Rasband 1997-2016).

\section{Pollen/Ovule Ratio (P/O)}

For determining the number of pollen grains per anther and per flower, and the number of ovules per ovary, we used five floral buds from different individuals corresponding to one population, following the technique described by Cruden (1977). Polen/ovule ratio (P/O) was calculated by the following calculation:

$\mathrm{P} / \mathrm{O}_{\text {SS-LS }}=$ mean pollen grains from flowers "S-morph"/ mean ovules from flowers "L-morph"

$\mathrm{P} / \mathrm{O}_{\mathrm{LS}-\mathrm{ss}}=$ mean pollen grains from flowers "L-morph"/ mean ovules from flowers "B-morph"

\section{Phenological studies}

The observations were made on cultivated material, corresponding to different populations: La Cruz and San Cosme. Fifteen floral buds per morph were marked before anthesis. Flowers were observed from anthesis (considered as the separation of petals) until the withering of the corolla. We also determined the floral longevity (estimated from withering of the corolla) and the moment when pollen is released. Stigmatic receptivity was determined as the separation of the stigma lobes and then it was corroborated in the laboratory using hydrogen peroxide $1 \%$ (Dafni \&
Maués 1988). For this test, we selected floral buds in a preanthesis state and open flowers $24,48,72$, and 96 hours after anthesis, of both morphs. For each variable analyzed we calculated: mean, maximum and minimum value, and standard deviation using Microsoft Excel 2010 and also we applied one-way ANOVA $(\alpha=0.001)$ using the software Past.

\section{Results}

\section{General structure of morphs}

Oldenlandia salzmannii is a marshy herb (Fig. 2A). The flowers are solitary or two per floral node (Fig. 2B). In both morphs, the flowers are perfect, tetramerous, actinomorphic, gamosepalous, gamopetalous, isostemonous, bicarpellate, with four epipetalous stamens and a nectary disc in the apical portion of the inferior ovary. Morphological structures were represented in figures 2 to 9 . The main difference between them is related to the style and stamen height. The LS flowers have a long style and included stamens (Figs. 2C, 3A) and the SS flowers have a short style and exerted stamens (Figs. 2D, 3B).

\section{Floral morpho-anatomy}

Floral whorls and different parts of both morphs are described simultaneously, highlighting the differences.

Calyx: four sepals are fused into a short tube (Figs. 2CD, 4A), and the ovate lobes may be glabrous or with simple hairs on their edges. Colleters are located in the sinuses between the calyx lobes, isolated or limited to small groups, and $0.10 \mathrm{~mm}$ in length on average (Figs. 4A-B). The calyx is persistent in the fruit.

Anatomically, the epidermis of the calyx lobes is onelayered with paracytic stomata (Fig. 5A). The trichomes are pluricellular and uniseriate, covered by a striated cuticle. The mesophyll is formed by a homogeneous chlorenchyma composed of compactly arranged polyhedral-rounded cells in cross section, leaving few intercellular spaces except for the substomatal chambers. In addition, raphides are abundant (Fig. 5A).

Colleters correspond to the standard type because they present a uniestratified epidermis which is composed of radially arranged cells, covering the parenchymatic central axis. The parenchymatous and epidermal cells present dense cytoplasm and voluminous nuclei (Fig. 5B).

Corolla: The corolla is mostly tetramerous (Fig. 2CD). However, pentamerous and trimerous corollas are exceptional. We observed a slight difference regarding the shape of the corolla between the morphs. The SS flowers are mainly tubular, and the LS flowers are urceolate (Fig. 2C-D). These differences could be due to dissimilarities in the corolla tube length, which is longer in SS flowers (Tab. 1). The corolla lobes are ovate. The aestivation is valvate. The 

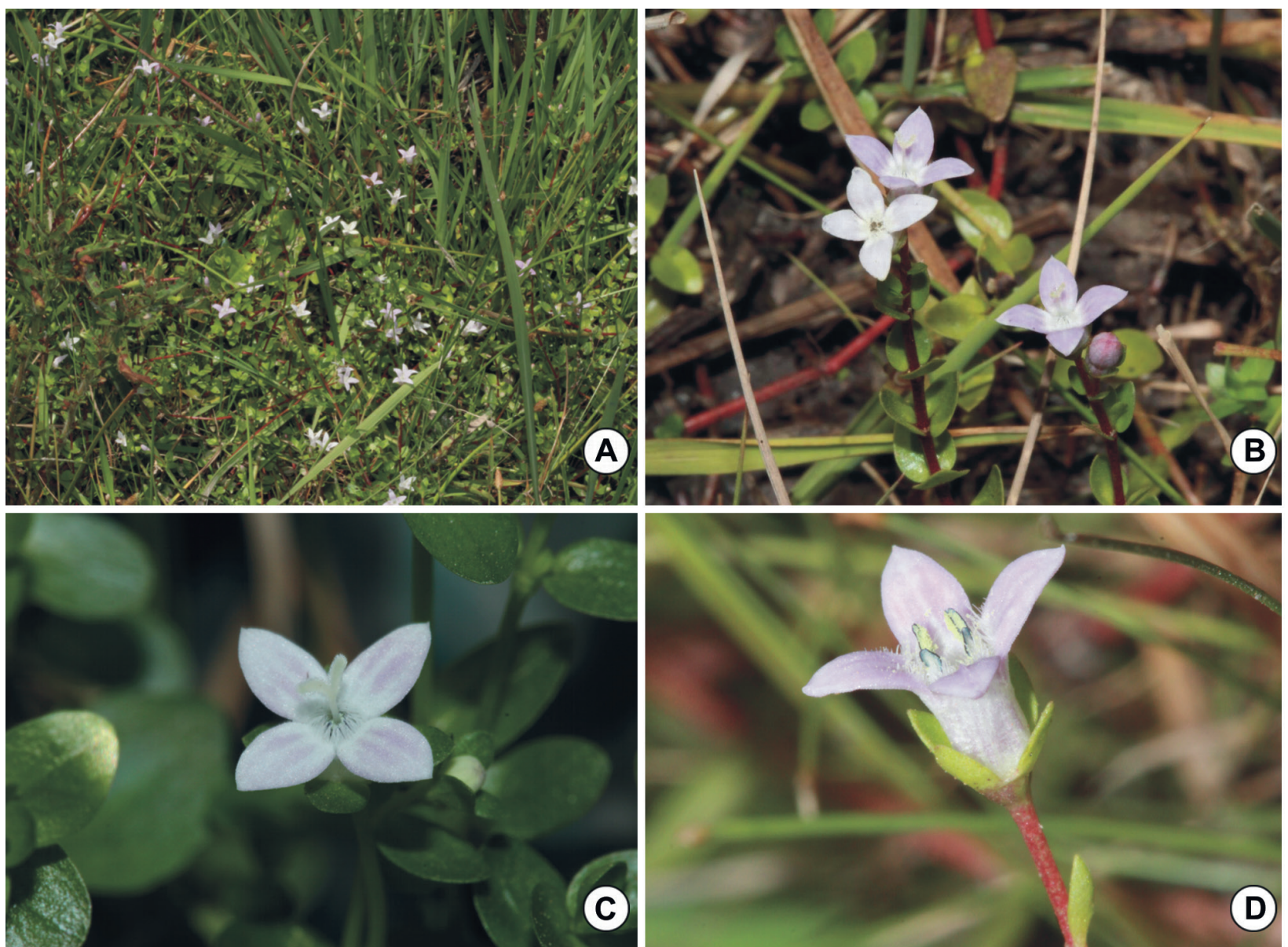

Figure 2. Habit and flowers of Oldenlandia salzmannii. A: Habit. B: Detail of inflorescence. C: LS flower. D: SS flower.
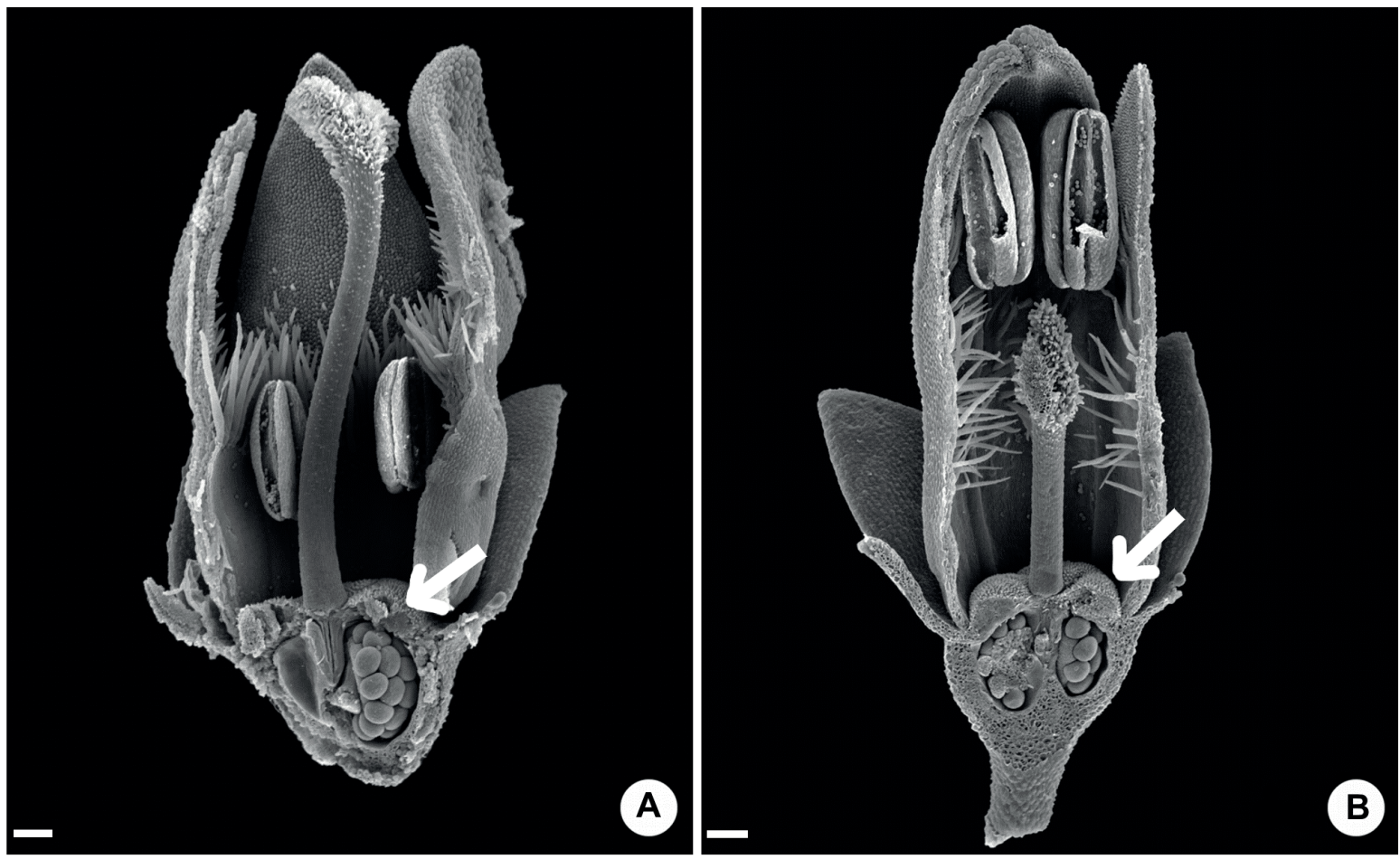

Figure 3. Flower morphology of Oldenlandia salzmannii (SEM). A: LS flower. B: SS flower, arrows: nectary disk. Scale bar: $200 \mu$ m. 
corolla is externally glabrous but hairy inside. In SS flowers, the trichomes form a band that spans to the upper twothirds of the corolla tube (Fig. 4C). However, in LS flowers, trichomes are present forming a ring at the height of the flower throat (Fig. 4D). Both morphs have the same types of trichomes: moniliform unicellular, simple unicellular and moniliform pluricellular (Fig. 4E-G). All these trichomes are covered by a striated cuticle, except for a few simple unicellular trichomes covered by a smooth cuticle.

The epidermis on the both surfaces of the corolla lobes is one-layered, papillate, without any stomata (Fig. 5C). At the abaxial surface, the epidermis presents cells with slightly convex outer walls, covered by a striated cuticle (Figs. 4H, 5C). At the adaxial surface, the epidermis presents long papillae with thin walls, covered by a striated cuticle except for the apex where the walls are thick and covered by a smooth cuticle (Figs. 4I, 5C). The mesophyll compound of parenchymatous and irregular cells in cross-section, which are arranged so that they leave large intercellular spaces (Fig. 5C). Large idioblasts, with raphides inside, are present (Fig. 5D).

Androecium: The filaments are fused with the corolla at the height of the flower throat (Fig. 5E). The anthers are dorsifixed, oblong and have longitudinal dehiscence (Fig. 4D). In LS flowers the stamens present very short filaments (Tab. 1), and the anthers are included (Figs. 3A, 4D). However in SS flowers, filaments are well developed (Tab. 1), and the anthers are exerted (Figs. 3B, 4C). In transverse section (Fig. 5F), the filament presents a onelayered epidermis with more or less quadrangular cells, covered by a slightly striated cuticle. The subepidermal parenchyma is composed of polyhedral-rounded cells in cross-section. A unique staminal bundle is located in the center. At maturity, the anther wall is only formed of an epidermis and an endothecium. At the connective level, the epidermis is continuous, and is formed by roundedrectangular cells in cross-section. At the thecae level, the epidermis is discontinuous and their cells are triangular in cross-section and the outer wall is convex. The endothecium is located around each pollen sac, and their cells are trapezoid-quadrangulate in cross-section with secondary thickenings in the form of bands. In the stomium region, cells of the endothecium are small, but the thickenings are still present. The connective is formed by parenchyma, and the unique staminal bundle ends there.

Pollen grains from SS flowers (Fig. 6A) are larger than pollen grains from LS flowers (Fig. 6B), although the variation ranges overlap partially. This difference in size is statistically significant (Tab. 2).

Gynoecium: The stigma is bifid (Figs. 3A-B, 4J), exceptionally trifid, and is of the papillate type with unicellular digitiform papillae covered by a smooth cuticle, which are located on the abaxial and adaxial surfaces. There is a slight difference in the length of the stigmatic papillae between morphs, but this difference is not statistically significant (Tab. 2).

The style is unique and anatomically it corresponds to the solid type (Fig. 5G). The epidermis is composed of more or less large cells, rounded to quadrangular in cross-section, covered by a thin cuticle. Subepidermal parenchyma is composed of rounded cells in cross-section which decrease in size from the periphery to the innermost, where there is a compact mass of transmission tissue of small, thick walled cells with dense cytoplasm. Two collateral vascular bundles run through the style and branch at the base of the stigma lobes.

The hypanthium is subglobose, mostly glabrous, although a few uniseriate pluricellular trichomes may be present. The ovary is inferior, bilocular pluriovulate, with axile placentation (Figs. 3A-B, 4K). The two locules are separated by a septum. Placentas are disk-like, peltate type, attached to the base of the septum by a thin peduncle (Fig. $5 \mathrm{H})$.

The wall of ovary, in cross-section, presents the following layers from the outside to the inside (Fig. 5I): the outer epidermis is one-layered and is composed of rectangular cells slightly covered by a striated cuticle. Paracytic stomata are present. The wall is composed of parenchyma, with polyhedral-rounded cells in cross-section. The vascular bundles corresponding to the ovary and hypanthium run through the parenchyma (see Vascularization). The two inner layers are composed of radially arranged rectangular cells in cross-section. The inner epidermis presents tangentially elongated cells, with no stomata.

The placenta is constituted of parenchymatous tissue and is vascularized by carpellate ventral bundles (Fig. $5 \mathrm{H})$. Raphides are abundant in both the hypanthium and placenta. The inner epidermis is differentiated into transmission tissue, with dense cytoplasm and a voluminous nucleus. After anthesis, the placenta increases in size, mainly due to increased intercellular spaces and it is considered as an intrusive placenta (Fig. 5J).

Ovule development: At maturation, the ovules are unitegmic and hemitropous (Fig. 7I-J). Carpel formation begins after the establishment of sepals, petals and stamens during flower ontogeny (Fig. 7A). The carpel margins rise due to periclinal cell divisions and the edges are closed forming the cavity ovarian. The edges of the carpel walls give rise to the style-stigma. At this stage, the placenta is common to both locules (Fig. 7B). Based on the pattern of cell divisions, the placenta has a tri-zonate structure, consisting of three layers: dermal, subdermal and central layer (Fig. 7C). The development of the ovule primordia begins with anticlinal cell divisions of the dermal and subdermal layers of the placenta (Fig. 7D). Periclinal and anticlinal cell divisions also occur in the central layer and contribute to the formation of the ovule primordium which takes a hemispherical form (Fig. 7E-F). In the subdermal layer, 2-3 cells are differentiated into archesporial cells, with a dense cytoplasm and prominent nucleus (Fig. 7F-G). Due to successive divisions, the ovule 

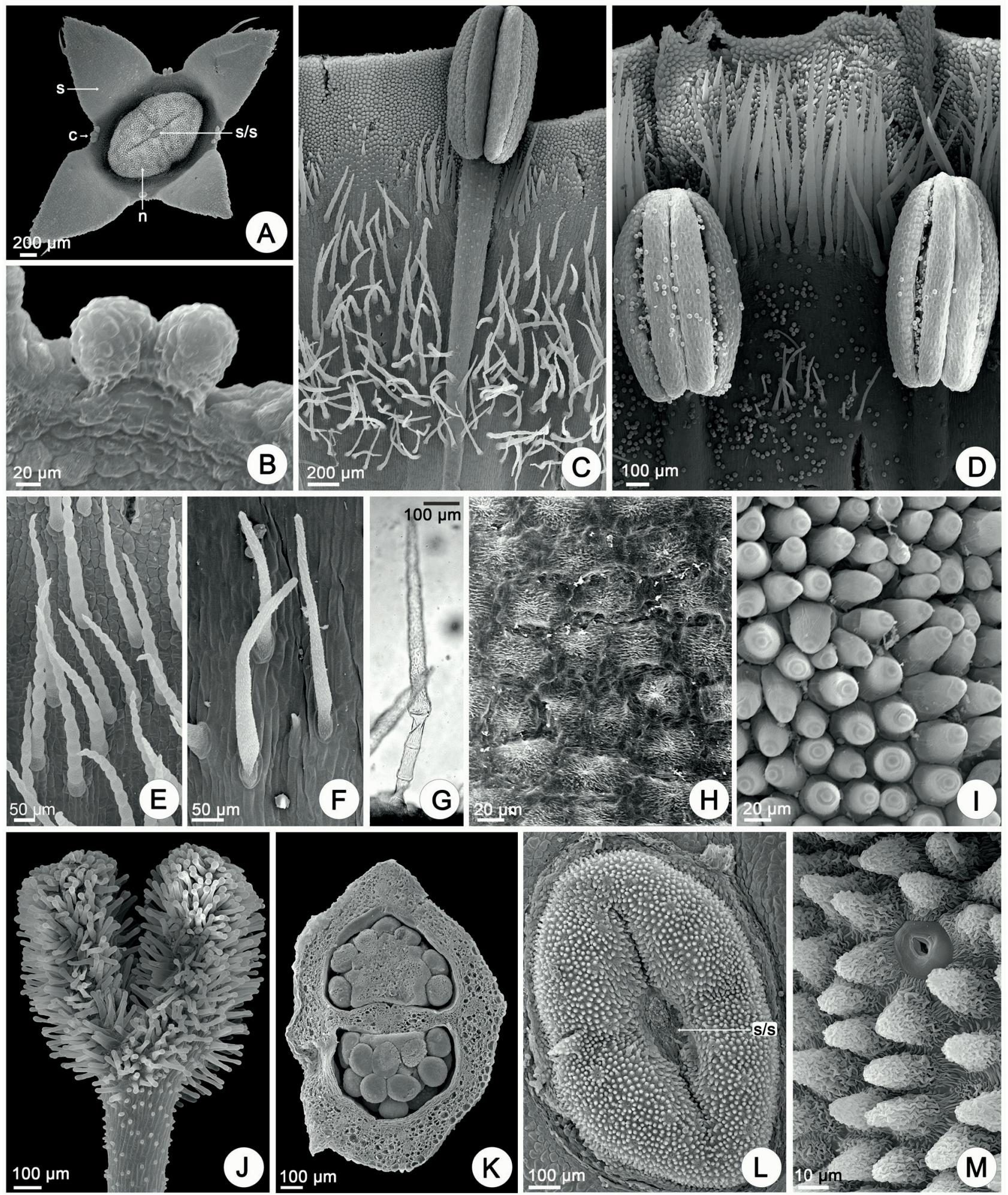

Figure 4. Micromorphological features of calyx, corolla, androecium, gynoecium and floral nectaries of Oldenlandia salzmannii (SEM). A: Top view of flower showing, (s) sepals, (co) colleters, (n) tetrapartite nectary disk and (s/s) stigma scar. B: Detail of sepalar colleters. C-D: Detail of the internal surface of the corolla. C: SS flower. D: LS flower. E: Moniliform trichomes. F: Simple trichomes. G: Pluricellular moniliform trichome. H: Detail of the outer surface of the corolla lobe. I. Detail of the inner surface of the corolla lobe. $\mathrm{J}$ : Detail of the bifid stigma. K: Cross section of the hypanthium/ovary showing pair of locules and placentation. L: Bipartite nectary disk, (s/s) stigma scar. M: Detail of nectarostoma. 

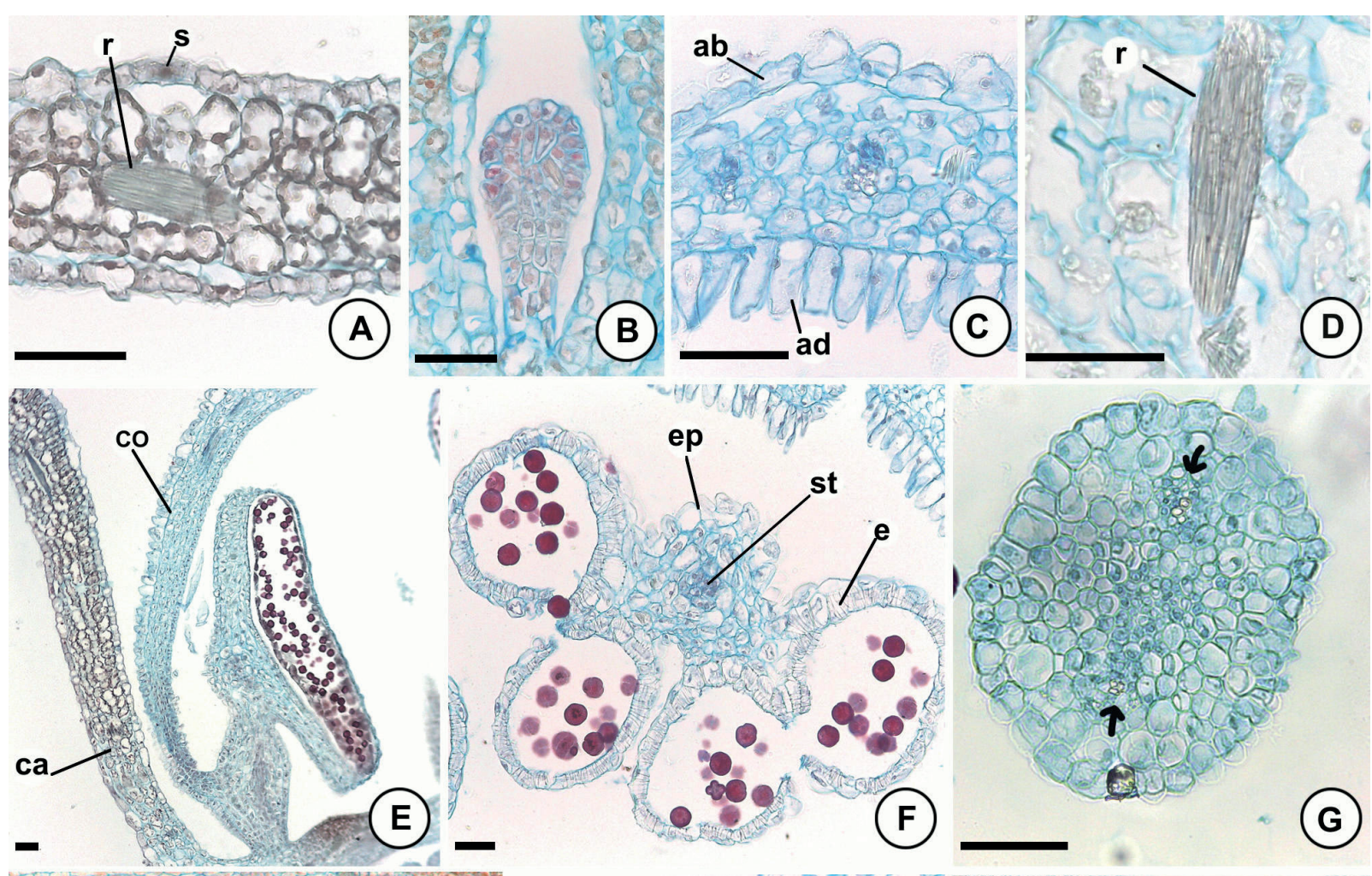

ep
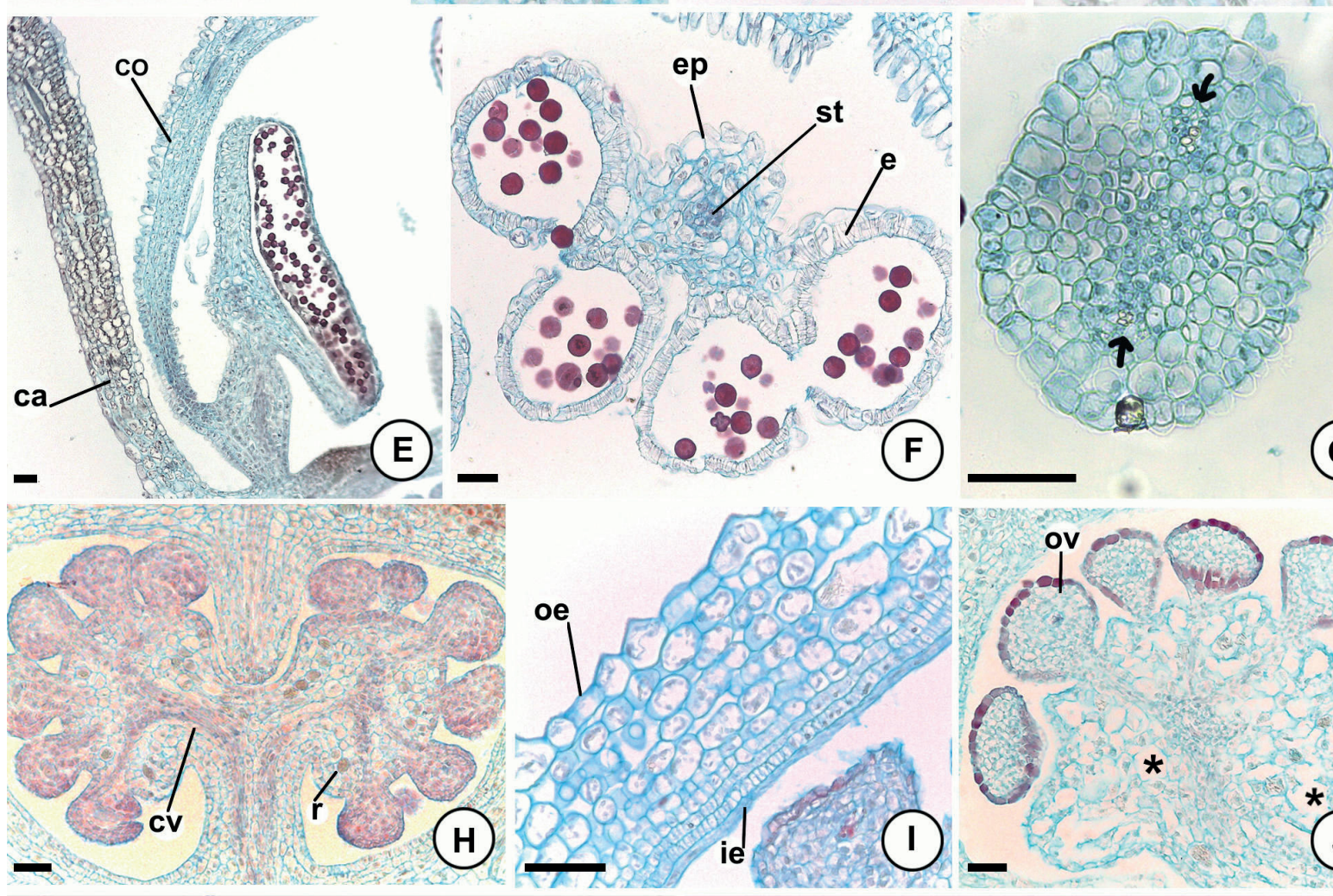

(G)
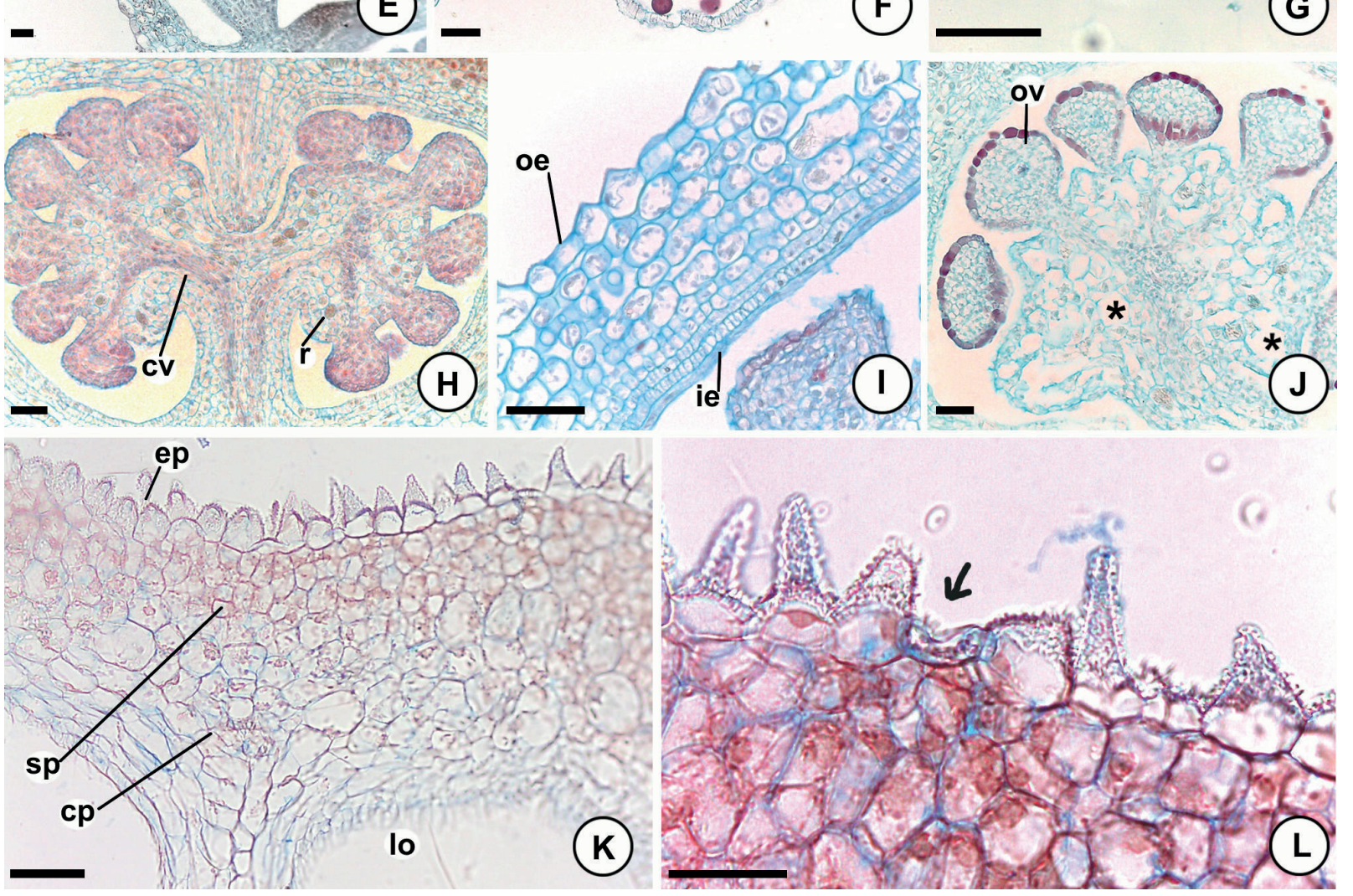

Figure 5. Anatomical description of calyx, corolla, androecium, gynoecium and floral nectaries (LM). A: Cross section of sepal. B: Longitudinal section of a colleter. C: Cross section of a corolla lobe. D: Detail of idioblast. E: Longitudinal section of a bud floral, showing a stamen adnate to the corolla. F: Cross section of a mature anther. G: Cross section of the style showing two vascular bundles (arrows). H: Longitudinal section of the ovary. I: Cross section of hypanthium/ovary. J: Longitudinal section of a mature placenta, (*) intercellular spaces. K: Longitudinal section of the nectary. L: Detail of the epidermis, showing a stoma (arrow) in longitudinal section. Abbreviations: (ab) abaxial surface of epidermis, (ad) adaxial surface of epidermis, (ca) calyx, (co) corolla, (cp) carpelar parenchyma, (cv) carpellate ventral bundles, (e) endothecium, (ep) epidermis, (ie) inner epidermis, (lo) locule, (oe) outer epidermis, (ov) ovule, (r) raphides, (s) stoma, (sp) secretory parenchyma, (st) staminal bundle. Scale bar: $50 \mu \mathrm{m}$. 
Table 1. Floral dimensions of SS flowers and LS flowers of O. salzmannii. $\bar{X}$ : mean; MAX: maximum value; MIN: minimum value; SD: standard deviation.

\begin{tabular}{|c|c|c|c|c|c|c|c|c|}
\hline \multirow{2}{*}{ Measures [mm] } & \multicolumn{4}{|c|}{ SS Flowers } & \multicolumn{4}{|c|}{ LS Flowers } \\
\hline & $\bar{x}$ & MAX & MIN & SD & $\bar{x}$ & MAX & MIN & SD \\
\hline Flower length & 6.89 & 8 & 5.71 & 0.66 & 5.97 & 7.56 & 5.17 & 0.55 \\
\hline Calyx length & 3 & 3.6 & 2.51 & 0.33 & 3.1 & 3.87 & 2.66 & 0.28 \\
\hline Calyx lobes length & 1.82 & 2.38 & 1.41 & 0.25 & 1.93 & 2.37 & 1.48 & 0.23 \\
\hline Calyx lobes width & 1.19 & 1.54 & 0.84 & 0.2 & 1.3 & 1.83 & 1.06 & 0.18 \\
\hline Corola length & 5.89 & 6.81 & 4.49 & 0.58 & 4.96 & 6.49 & 3.99 & 0.58 \\
\hline Corola tube length & 2.64 & 3.26 & 2.03 & 0.34 & 1.78 & 2.18 & 1.46 & 0.18 \\
\hline Corola lobes length & 3.27 & 3.75 & 2.59 & 0.32 & 3.28 & 4.04 & 2.62 & 0.38 \\
\hline Corola lobes width & 1.87 & 2.12 & 1.5 & 0.18 & 1.87 & 2.2 & 1.36 & 0.2 \\
\hline Style-stigma height & 2.13 & 2.5 & 1.5 & 0.27 & 4.14 & 4.68 & 3.56 & 0.34 \\
\hline Style length & 1.23 & 1.62 & 0.83 & 0.2 & 3.16 & 3.8 & 2.58 & 0.36 \\
\hline Stigma length & 1.06 & 1.37 & 0.83 & 0.14 & 1.04 & 1.35 & 0.51 & 0.19 \\
\hline Stamen height & 4.28 & 5.27 & 3.54 & 0.46 & 1.97 & 2.38 & 1.75 & 0.16 \\
\hline Filament length & 3.59 & 4.5 & 2.66 & 0.48 & 1.52 & 1.83 & 1.26 & 0.17 \\
\hline Anther length & 1.09 & 1.26 & 0.87 & 0.11 & 0.82 & 0.96 & 0.68 & 0.07 \\
\hline Anther width & 0.49 & 0.65 & 0.33 & 0.09 & 0.45 & 0.58 & 0.29 & 0.07 \\
\hline
\end{tabular}

Table 2. Floral and anatomical microcharacter dimensions between SS flowers and LS flowers of O. salmzmannii. $\overline{\mathrm{X}}$ : mean; MAX: maximum value; MIN: minimum value; DE: standard deviation; $F$ value and significance value $(\mathrm{P}=0.001)$ of ANOVA.

\begin{tabular}{|c|c|c|c|c|c|c|c|c|}
\hline \multirow[b]{2}{*}{ Medidas [ $\mu \mathrm{m}]$} & \multicolumn{3}{|c|}{ SS Flowers } & \multicolumn{3}{|c|}{ LS Flowers } & \multicolumn{2}{|c|}{ ANOVA } \\
\hline & $\bar{x}$ & MAX & MIN & $\bar{x}$ & MAX & MIN & $\mathbf{F}$ & $\mathbf{P}$ \\
\hline Pollen: equatorial diameter (E) & 34.72 & 38.13 & 31.42 & 31.37 & 35.11 & 27.79 & $\mathrm{~F}={ }_{1.39} 28.88$ & $<0.001$ \\
\hline Pollen: polar axis $(\mathrm{P})$ & 34.04 & 36.64 & 31.75 & 30.66 & 33.75 & 27.05 & $\mathrm{~F}={ }_{1.39} 236.9$ & $<0.001$ \\
\hline Stigmatic papilla length & 105.43 & 149.61 & 70.95 & 103.79 & 168.14 & 61.56 & $\mathrm{~F}={ }_{1.199} 2.05$ & $>0.001$ \\
\hline Nectary disk area & 0.71 & 0.92 & 0.56 & 0.81 & 1.172 & 0.65 & $\mathrm{~F}={ }_{1.19} 2.34$ & $>0.001$ \\
\hline Papillae of nectary disk length & 30.16 & 37.95 & 16.84 & 29.52 & 39.15 & 22.7 & $\mathrm{~F}={ }_{1.59} 1.26$ & $>0.001$ \\
\hline Oclusive cells of nectarostomata length & 21.13 & 27.01 & 15.53 & 22.31 & 29.35 & 15.47 & $\mathrm{~F}==_{1.199} 10.02$ & $>0.001$ \\
\hline Oclusive cells of nectarostomata width & 6.96 & 9.49 & 4.71 & 7.39 & 7.39 & 5.44 & $\mathrm{~F}={ }_{1.199} 9.96$ & $>0.001$ \\
\hline
\end{tabular}

grows and starts the hemitropous curvature (Fig. 7G-H). Periclinal divisions occurred in the dermal layer resulting in the formation of the single integument (Fig. $7 \mathrm{H}$ ). The nucellar epidermis, consisting of 1-2 cells, has a flat surface during the whole development of the ovule. The archesporial tissue is included in the nucellus at a right angle to the insertion of the ovule (Fig. 7G-H).

The mature ovule, with the embryo sac completely formed, maintains the hemitropous curvature; the integument epidermis is composed of cells with a red content, probably tannins. Besides, a considerable increase in the ovule size is observed (Figs. 7I-J; 8).

Floral nectaries: A nectary disk, tetrapartite (Fig. 4A) or bipartite (Fig. 4L) fully covers the apical portion of the ovary (Fig. 3A-B). A slight difference in respect to the nectary size is observed between morphs (Tab. 2). In transverse section, the epidermis is one-layered and is composed of papillate cells covered by a striated cuticle (Fig. 5K-L). The length of the papillae is uniform all over the nectary disk (Tab. 2). Nectarostomata are randomly distributed across the surface of the nectary and are located at the level of the other epidermal cells (Fig. 5L). Each nectarostoma is surrounded by $5-7$ subsidiary cells arranged in a rosette (Fig. 4M). Below the epidermis, the nectary presents 7-10 layers of secretory parenchyma (Fig. 5K), which consists of small isodiametric cells compactly arranged with a prominent nucleus and dense cytoplasm. Raphides are abundant. Underneath the secretory parenchyma, several layers composed of larger loosely arranged polygonal cells can be distinguished which correspond to the carpelar parenchyma.

Floral vascularization: The floral pedicel is vascularized by a siphonostele (Fig. 9A, K). The receptacle is ovate in cross-section; the siphonostele is divided into 6 vascular bundles below the locules (Fig. 9B, L). In the SS flower, two 


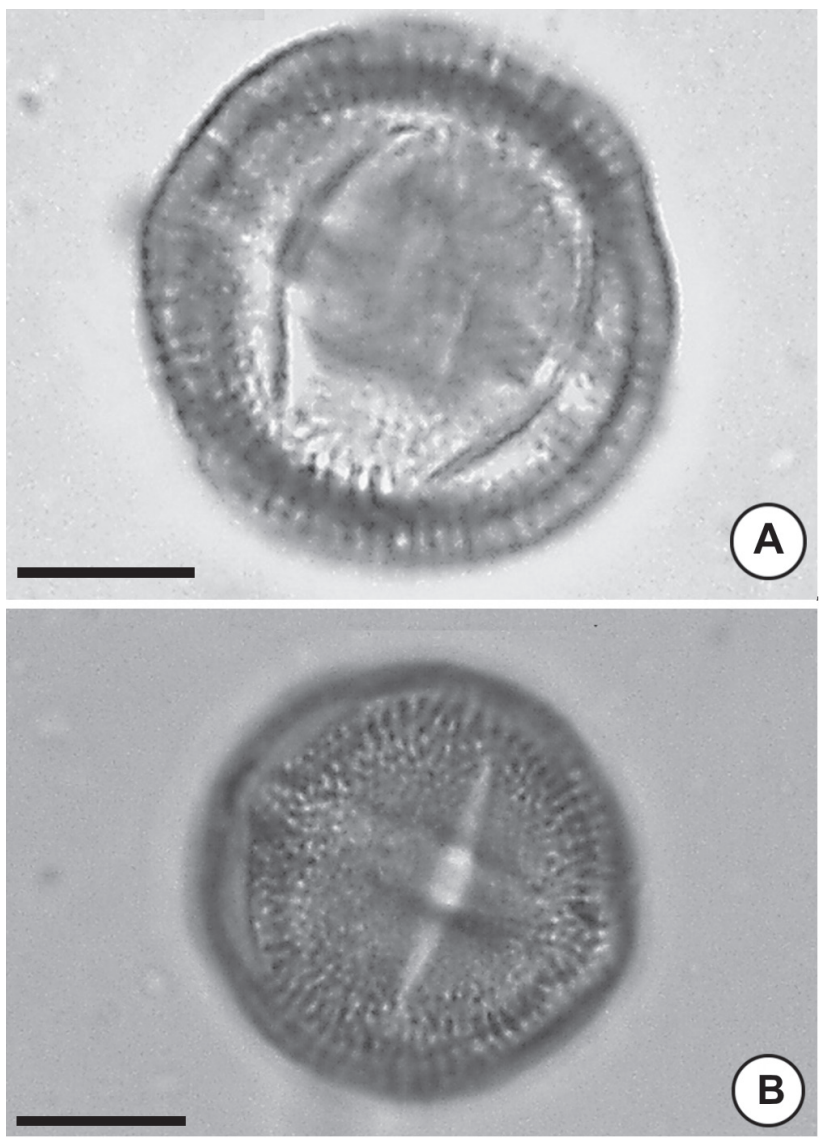

Figure 6. Pollen morphology of Oldenlandia salzmannii (LM). A-B: Equatorial view. A: Pollen grain of SS flower. B: Pollen grain of LS flower. Scale bar: $10 \mu \mathrm{m}$.

small traces go to the center of the flower and will become the ventral bundles of the two carpels (Fig. 9B-C). However, in the LS flower, four traces go to the center of the flower (Fig. 9L-M). In both morphs, these bundles vascularized the septum which divides the two locules of the ovary (Fig. 9D, $\mathrm{N}$ ) and then enter into the placenta where they subdivide and end, irrigating the ovules through the funicle (Fig. 9E, $\mathrm{O}$ ). Of the six vascular bundles of the receptacle, two bundles are larger, and they are located in the periphery (Fig. 9C, M) and from them, two minor traces are separated, leaving a total of eight peripheral bundles at the base of the locules. In both morphs, from the eight peripheral bundles, two of them represent the sepal-staminal complex and the other two vascular bundles represent the sepal-stamino-carpelar complex; the remaining four bundles will give rise to the dorsal bundles of each petal (Fig. 9D, N).

At the top of the ovary (Fig. 9J, T), the sepal-stamino complex bifurcates (Fig. 9F, P). The trace, which will constitute the dorsal bundle of the sepal, migrates out and the staminal trace migrates to the interior. When the calyx lobes are separated, each sepal is vascularized by a dorsal bundle and by two or more lateral bundles (Fig. 9G, Q). The staminal bundle runs through the filament and ends in the connective between the thecae (Fig. 9E-I, O-R). The sepal-stamino-carpelar complex is divided into three traces at the top of the ovary (Fig. 9E, O). The vascular bundles of the sepal and stamen are the same as described above. Moreover, the third trace constitutes the dorsal bundle of the carpel, which runs through the apex of the ovary and into the style. These two bundles continue through the style and then into the stigma-lobes (Fig. 9E-G, O-S).

At the base of the corolla-tube, the dorsal petal bundle bifurcates, constituting a total of three vascular bundles (Fig. 9F-G, P-Q). At the level of the corolla lobes, the bundles divide a few times more to constitute the vascular network (Fig. 9H-I, R-S).

\section{Floral morphometry}

The SS flowers have corollas significantly larger than the LS flowers, and this is due to differences in the length of the corolla tube, as there are no significant differences in the length of the corolla-lobes. The length of the anthers is statistically different and longer in SS flowers. Differences in the size of stigmatic lobes are not significant (Tab. 3). The absolute difference between the stamens and stylestigma height (reciprocal herkogamy), is not significant (Tab. 3). This indicates that the spatial difference between the style-stigma and stamens is similar in both morphs. The herkogamy reciprocity index (HK) calculated for SS flowers is 1.08 , and the herkogamy reciprocity index for LS flowers is 0.96 , which denotes an almost perfect reciprocity in the height of the sexual organs. Figure 10 shows the relationship between style-stigma and anther length in each morph.

\section{Pollen/ovule ratio}

There are no significant differences $\left(\mathrm{F}_{1,4}: 0.011 \mathrm{P}>0.001\right)$ between the morphs in respect to the production of pollen per anther (Tab. 4). Likewise, the differences in the number of ovules per flower, between SS and LS flowers (Tab. 4), are not significant $\left(\mathrm{F}_{1,4}: 0.121 \mathrm{P}>0.001\right)$.

The P/O ratio for SS flowers is 129.19 and 141.87 for LS flowers.

\section{Floral phenology}

Anthesis is diurnal, around 8-11 am. Most flowers have pinkish-purple corolla-lobes with darker pink lines marked on each lobe (nectar guides) and a completely white corolla-tube (Fig. 2C-D). Completely white flowers were also observed.

In both morphs (Fig. 11A-H), the pollen starts being released before anthesis and is exposed on the surface of the anther. When the flower opens, the stigmatic lobes are already separated indicating receptivity. The stigma, in both morphs, is receptive in the floral buds just before anthesis and in the flowers up to 96 hours after anthesis (Fig. 11I-L). 


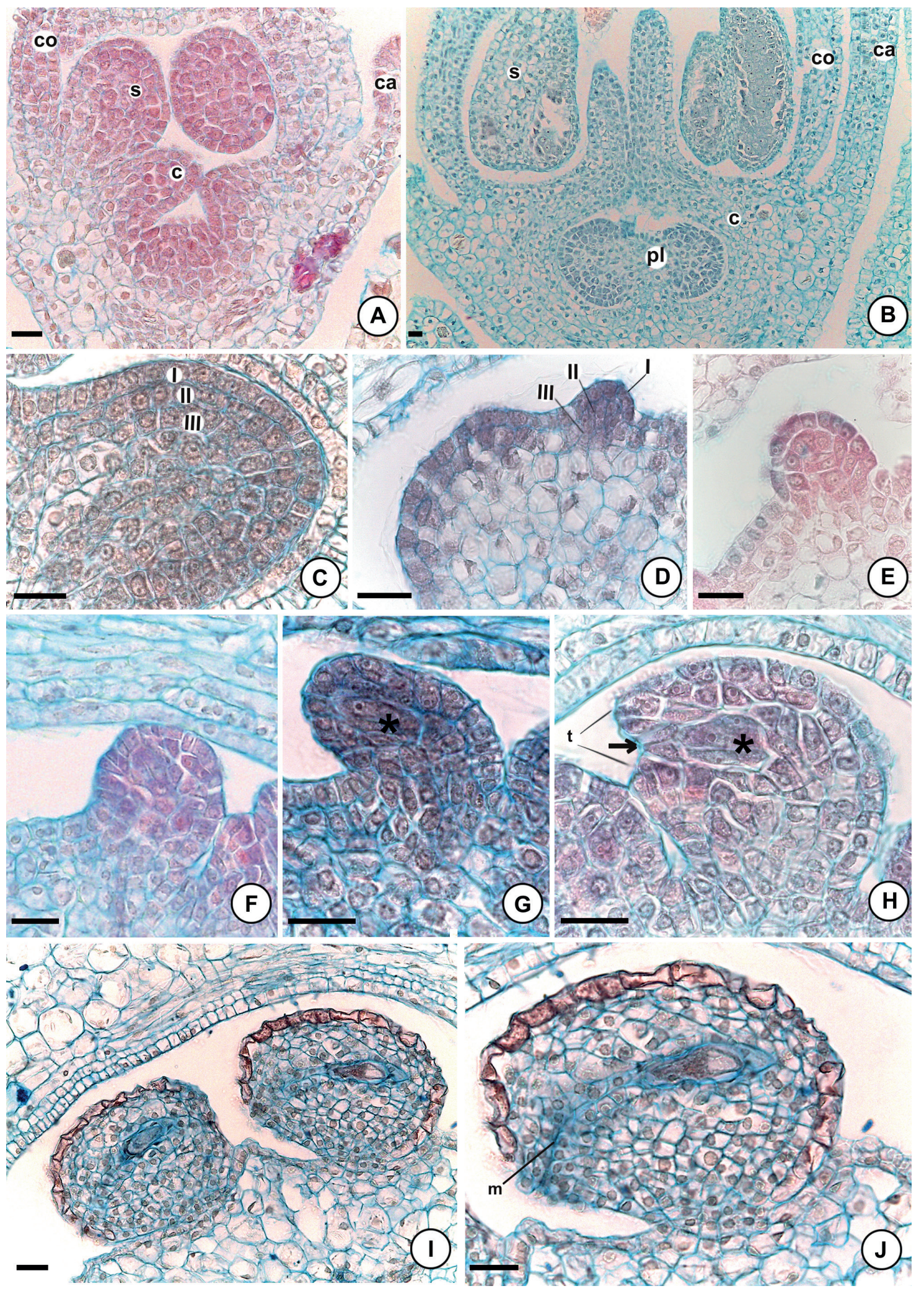

Figure 7: Ovule development of Oldenlandia salzmannii (LM). A: Early development of flower. B: The edges of the carpels are closed forming the ovarian cavity. C: Detail of the placenta tri-zonate structured. D: Young ovule, tri-zonate structure. E-F: Detail of the hemispherical ovule primordium during the hemitropous curvature. G: Detail of the ovule with archesporial cells $\left(^{*}\right)$. H: Detail of the hemitropus ovule, more developed, with nucellar epidermis (arrow) and archesporial cells $\left(^{*}\right)$. I: Portion of the locule, showing two mature ovules. J: Detail of a mature ovule. Abbreviations: (c) carpel, (ca) calyx, (co) corolla, (I) dermal layer, (II) subdermal layer, (III) central layer, (m) micropyle (pl) placenta, (s) stamen, (t) integument. Scale bar: $20 \mu \mathrm{m}$. 
In LS flowers at the moment of anthesis, we observed that the stigma may present two different positions in respect to the style: upright stigmas (Fig. 11F) and bent stigmas (Fig. 11G). The latter type of stigma remains in its position with the passing hours without changing. Both types of stigmas were receptive.

Floral longevity was similar in both morphs, being on average 3.4 days (83 hours) for SS flowers and 4.3 days (105 hours) for LS flowers. We observed in both morphs that the corolla and style drop together in most cases after floral withering.

\section{Discussion}

As we mentioned earlier, some aspects of the reproductive biology of Oldenlandia salzmannii have already been studied by Riveros et al. (1995). While their study provided important data, such as the capacity of self-compatibility, it did not include the morphological characterization of both morphs. Therefore the realization of the present study has allowed us to provide essential information about the morpho-anatomy and some aspects of the reproduction. With these data, we make a contribution to the knowledge about this species that belongs to a conflictive group, and which will help to clarify this issue.

\section{Corolla}

In Oldenlandia salzmannii there is a difference in the shape of the corolla between morphs. The LS flowers tend to have an urceolate shape, unlike the SS flowers which have a tubular shape. Cabral (2009) also observed this type of dimorphism in floral morphs of Galianthe centranthoides, a

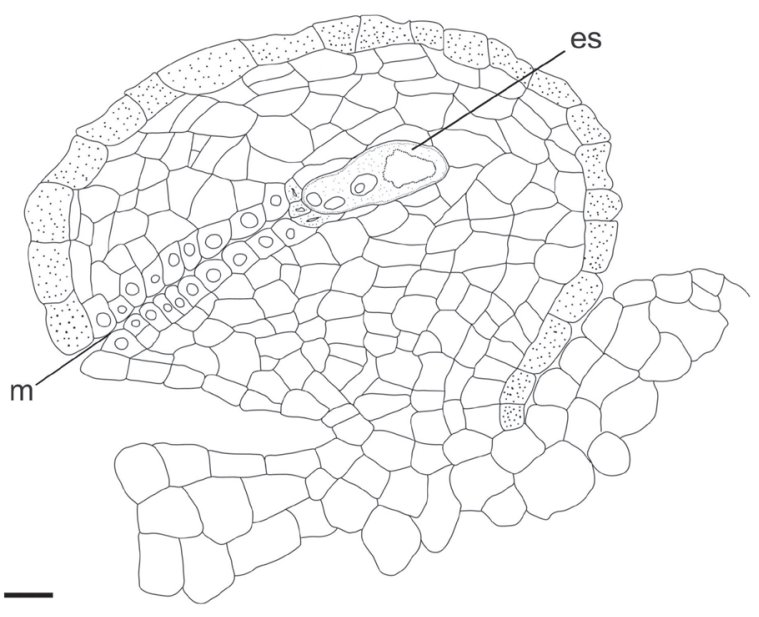

Figure 8. Diagrammatic representation of a mature ovule of Oldenlandia salzmannii, showing its hemitropous position. Abbreviations: (es) embryo sac, (m) micropyle. Scale bar: $20 \mu \mathrm{m}$.

species belonging to the Spermacoceae tribe. According to Ganders (1979) heterostylous species frequently present a slight difference in the shape of the corolla tube between morphs. This is due to a slight bulge low down in the tube where the anthers are attached in the LS flowers; consequently, these flowers have an enlarged shape. In the species studied, the difference between morphs is due to this reason revealed by Ganders, in addition to differences present in the length of the corolla tube.

Moreover, in O. salzmannii there is a difference in the corolla length between morphs, the corolla of the SS flowers being larger than the LS flowers, which is due to differences

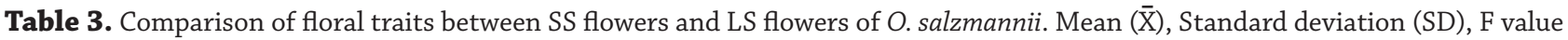
and significance value $(\mathrm{P}=0,001)$ of ANOVA.

\begin{tabular}{|c|c|c|c|c|c|c|}
\hline \multirow{2}{*}{ Floral trait } & \multicolumn{2}{|c|}{ SS flowers } & \multicolumn{2}{|c|}{ LS flowers } & \multicolumn{2}{|c|}{ ANOVA } \\
\hline & $\bar{x}$ & SD & $\bar{x}$ & SD & $F_{139}$ & $\mathbf{P}$ \\
\hline Stamens height & 4.28 & 0.46 & 1.97 & 0.16 & 444.5 & $<0.001$ \\
\hline Anther length & 1.09 & 0.11 & 0.82 & 0.07 & 76.21 & $<0.001$ \\
\hline Style-stigma height & 2.13 & 0.27 & 4.14 & 0.34 & 407.4 & $<0.001$ \\
\hline Stigma length & 1.06 & 0.14 & 1.04 & 0.19 & 0.1238 & $>0.001$ \\
\hline Corolla length & 5.89 & 0.58 & 4.96 & 0.58 & 25.29 & $<0.001$ \\
\hline Corolla tube length & 2.64 & 0.34 & 1.78 & 0.18 & 98.88 & $<0.001$ \\
\hline Corolla lobule length & 3.27 & 0.32 & 3.28 & 0.38 & 0.0032 & $<0.001$ \\
\hline Reciprocal herkogamy & 2.17 & 0.53 & 2.17 & 0.27 & 0.0011 & $>0.001$ \\
\hline
\end{tabular}

Table 4. Pollen grains per anther, per flower and ovules per flower in O. salzmannii. X: mean; SD: standard deviation.

\begin{tabular}{|l|c|c|c|c|c|c|} 
& \multicolumn{2}{|c|}{ Pollen grains per anther } & \multicolumn{3}{|c|}{ Pollen grains per flower } & \multicolumn{3}{|c|}{ Ovules per flower } \\
\hline Floral morph & $\overline{\mathbf{X}}$ & SD & $\overline{\mathbf{X}}$ & SD & $\overline{\mathrm{X}}$ & SD \\
\hline SS flower & 1724.8 & 219.99 & 6899 & 879.98 & 49 & 15.1 \\
\hline LS flower & 1738 & 165.43 & 6952 & 661.75 & 53.4 & 23.8 \\
\hline
\end{tabular}




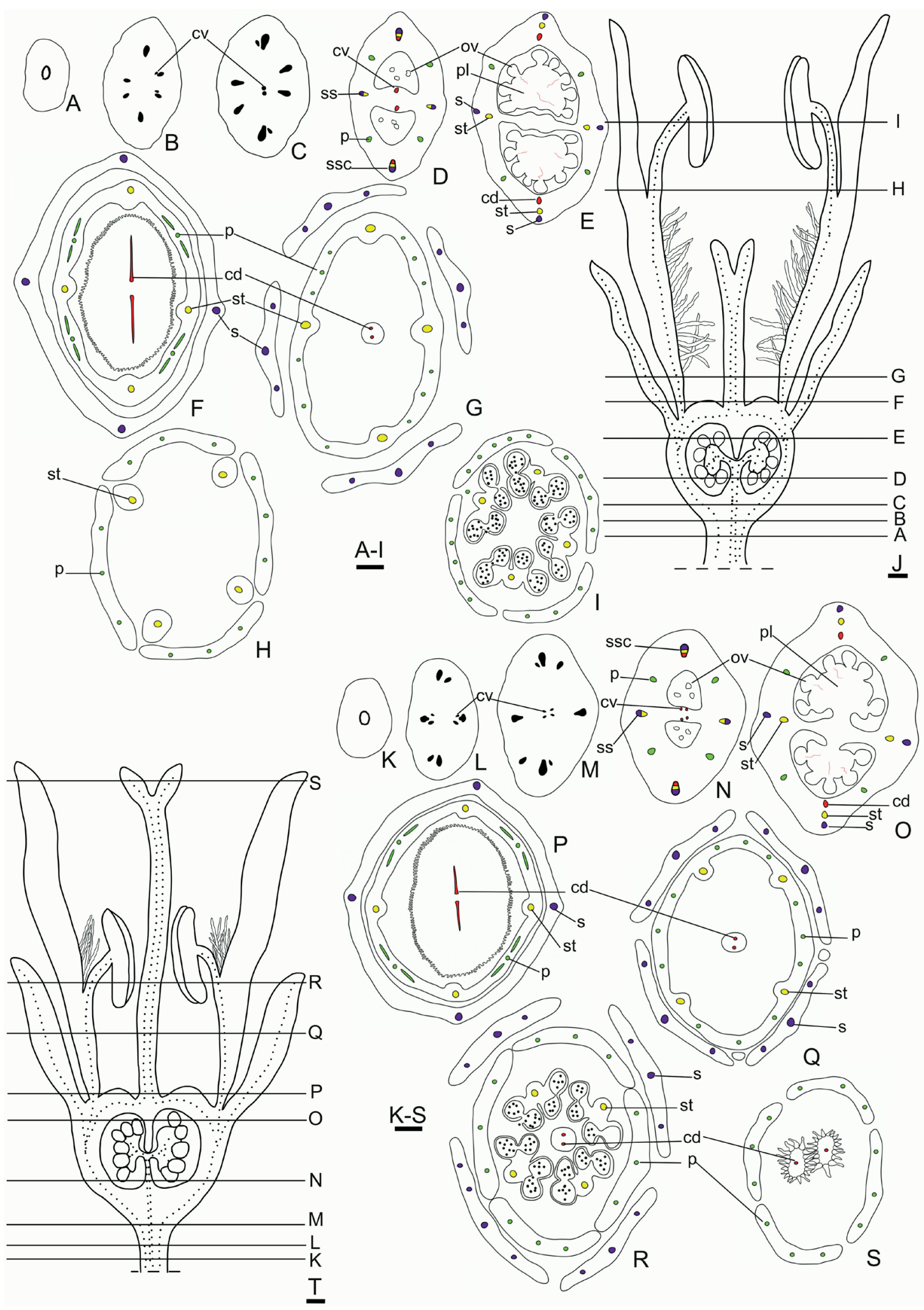

Figure 9: Floral vascularization of Oldenlandia salzmannii. A-I: SS flower, transverse sections of the flowers at the levels indicating in J. K-S: LS flower, transverse sections of the flowers at the levels indicating in T. J, K: Longitudinal section of the flower. Abbreviations: cd: carpelar dorsal bundle, cv: carpelar ventral bundle, ov: ovule, p: petal bundle, pl: placenta, s: sepal bundle, ss: sepal-stamino complex, ssc: sepal-stamino-carpelar complex, st: staminal bundle. Scale bar: A-I, K-S: $200 \mu \mathrm{m}$. J, T: 1 mm. 


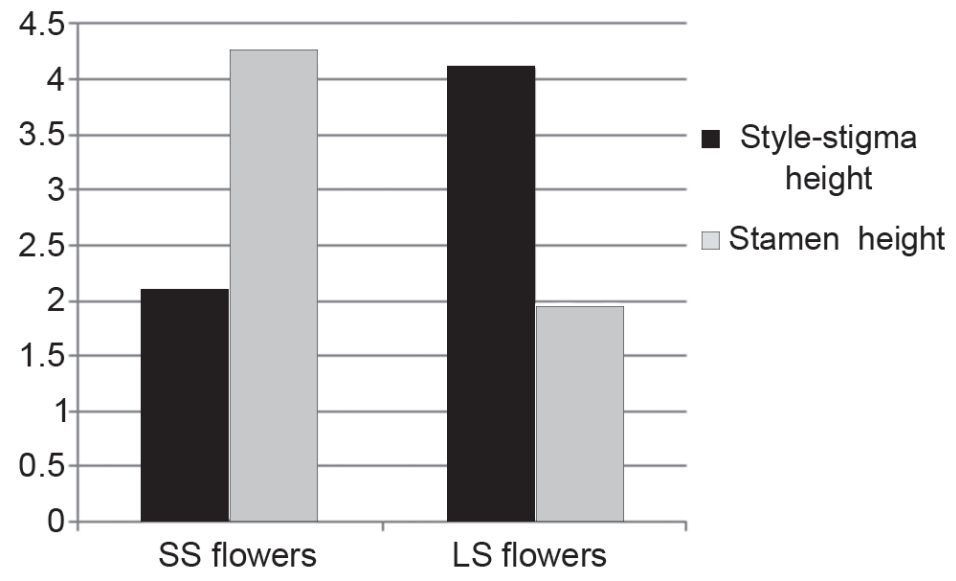

Figure 10: Relationship between style-stigma and anther length in each morph of Oldenlandia salzmannii.
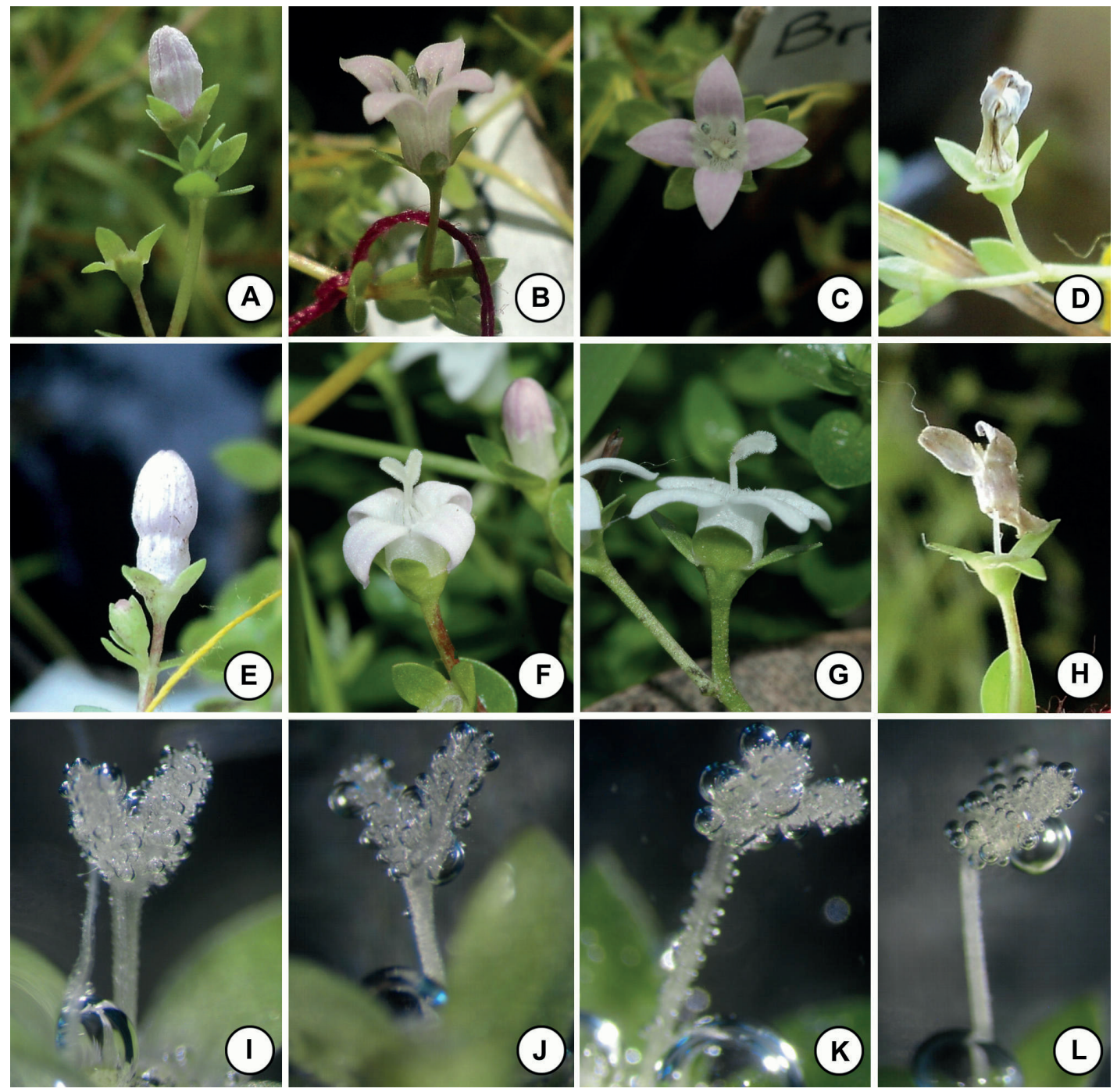

Figura 11: Floral phenology and stigmatic receptivity in Oldenlandia salzmannii. A-H: Floral phenology. A-D: SS flowers. E-H: LS flowers. A: Floral bud. B-C: Anthetical flower. B: Lateral view. C: View from above showing the stigmatic lobes already separated. D: Flower 72 hours after anthesis. E: Floral bud. F: Flower with right stigma. G: Flower with bent stigma. H: Flower 96 hours after anthesis. I-L: Stigmatic receptivity. I-J: SS flowers. K-L: LS flowers. I, K: one hour after anthesis. J: 72 hours approx. after anthesis. K: 96 hours approx. after anthesis. 
in the length of the corolla tube. This type of dimorphism is one of the most common among distylous species, and in most cases the SS flowers have larger corollas; this also occurs in other species of Rubiaceae, such as Bouvardia ternifolia (Faivre \& McDade 2001), Palicourea padifolia (Hernández \& Ornelas 2003), Palicourea petiolaris (Sobrevila et al. 1983) and Psychotria carthagenensis (Koch et al. 2010), etc. Ganders (1979) states that there is no evidence for the dimorphism in corolla size, but it might possibly be related to the asymmetric pollen flow. If the larger corollas preferably attract the pollinators, this dimorphism would increment the frequency of the visits of pollinators towards SS flowers, which could compensate for the lower capture of pollen from SS flowers.

A difference is observed in the internal indument of the corolla between LS and SS flowers of Oldenlandia salzmannii. According to Ganders (1979), this dimorphism is rare among heterostylous species, however, it has been recorded in several distylous species of the Spermacoceae tribe, mainly in species of Galianthe (Cabral 2009).

\section{Anther and Pollen}

The two floral morphs of Oldenlandia salzmannii present a difference in the anther size, the SS flowers having longer anthers. This dimorphism was reported for the first time by Darwin (1877). The difference was recorded in others species of Rubiaceae, such as Psychotria carthagenensis (Koch et al. 2010), Psychotria nuda (Castro \& Araujo 2004) and $P$. poeppigiana (Coelho \& Barbosa 2004).

We also recorded a difference in the pollen size between morphs of $O$. salzmannii, where the pollen grains of SS flowers are larger. This dimorphism has already been recorded in a floral biology study by Riveros et al. (1995) in which the size of the pollen grains was presented but without specifying the average measurements of the polar and equatorial axes. Although the results of the present study coincide with those observed by Riveros et al. (1995), there is a difference in the numerical values obtained. On the other hand, Riveros et al. (1995) indicate that LS flowers have a greater number of pollen grains per anther than the SS flowers. Those results do not coincide with our results because there were no differences in the production of pollen per anther between the morphs. As the amount of pollen grains per anther in both morphs is similar, and as the pollen grains of SS flowers are larger, it is logical that there is a slight difference in the anther size.

The dimorphism in anther size has been related to the size of pollen grains. The differences in pollen size between morphs and the number of pollen grains per anther are the principal polymorphism characteristics correlated with heterostyly (Ganders 1979; Dessein et al. 2005), as there is a correlation between pollen size and number of pollen grains which results in many small grains or in a few large grains. Pollen dimorphism in respect to the size is so frequent in distylous taxa that Darwin (1877) considered it a basic characteristic of heterostyly. According to Dulberger (1974), pollen heteromorphism has been reported in 50 of 55 heterostylous genera examined. As a general rule the pollen of SS flowers is slightly larger than the LS flower pollen (Darwin 1877; Sobrevila et al. 1983; Pire \& Cabral 1992; Coelho \& Barbosa 2004). Nonetheless, in some species of Rubiaceae, such as Pentas schimperiana (Dessein 2003), Pseudosabicea arborea (Huysmans et al. 1998) and Hindsia longiflora (Maio 1996), the pollen grains of the LS flowers are larger than the pollen grains of the SS flowers.

\section{Stigma}

From the morph-anatomical analysis under light microscope and SEM, our results reveal no differences between morphs with respect to the shape and length of the stigma, nor in the shape and size of the stigmatic papillae. However, these results are not coincident with those of Riveros et al. (1995) who stated that Oldenlandia salzmannii presented a difference in the shape of stigmas, as can be seen in the illustration of the floral morphs provided. According to Dulberger (1974) stigma surface heteromorphism has been reported in 39 of 53 genera examined from different families. Dulberger (1992) suggested that stigma shape is also variable between morphs, since SS flowers have elongated stigmas that increase the pollen capture which could lead to greater reproductive success. Despite the fact that this dimorphism is unrecorded in $O$. salzmannii, some Rubiaceae species, such as Palicourea fendleri (Sobrevila et al. 1983), Psychotria carthagenensis (Koch et al. 2010) and P. poeppigiana (Coelho \& Barbosa 2004), have SS flowers with stigma lobes that are longer than the stigma lobes of the LS flowers.

\section{Reciprocity}

From the floral morphometry study realized on Oldenlandia salzmannii, it is observed that the difference between style-stigma and stamen height within flowers did not differ between the floral morphs, and given the index of reciprocity obtained we can state that this species has a high degree of herkogamy reciprocity. The reciprocal position of stamen and style-stigma heights is one of the characteristics that defines heterostyly (Ganders 1979; Richards \& Barret 1992). Therefore, the absolute value of the difference in the stamen and style-stigma heights between SS flowers and LS flowers should be equal between floral morphs. Herkogamy reciprocity is an essential component in models explaining the evolution and maintenance of heterostyly based on enhanced outcrossing (Faivre \& McDade 2001). Already in 1877, Darwin proposed that the reciprocal position of the sexual organs in flowers of heterostylous plants would be an adaptation which facilitates pollen exchange between plants of different morphs due to the segregation of pollen 
in different parts of the pollinator body which is supported by recent studies (Massinga et al. 2005; Keller et al. 2014). As we mentioned earlier, O. salzmannii presents a high degree of herkogamy reciprocity, but many other distylous species of Rubiaceae present a considerable variation in the distance between style-stigma and stamen heights between morphs, so the herkogamy reciprocity is not perfect. This occurs for example in: Palicourea padifolia (Hernández \& Ornelas 2003); P. officinalis (Consolaro et al. 2009), Psychotria chiapensis (Faivre \& McDade 2001) and P. poeppigiana (Coelho \& Barbosa 2004), etc.

Despite the results obtained it would be interesting to perform a morphometry study involving a few more populations in future studies to see if the results are the same; this is because heterostyly may vary between populations (Faivre \& McDade 2001).

\section{Pollen-ovule ratio}

Following the classification of Cruden (1977), the P/O ratio for both morphs indicates that Oldenlandia salzmannii shows facultative xenogamy. This is evident in the study of Riveros et al. (1995), as legitimate pollination produced the highest percentage of fruits per pollination. In the same study, (Riveros et al. 1995), they confirmed that the species is self-compatible and they recorded fruit production after manual self-pollination, although in a smaller percentage.

\section{Phenology}

The longevity of flowers in Oldenlandia salzmannii (4.3 days in LS flowers and 3.4 days in SS flowers) is greater than the average longevity (1.37 days) recorded for other species of Rubiaceae (Stratton 1989); according to Dulberger (1992) heterostylous flowers have a short longevity, lasting just one to two days. Riveros et al. (1995) recorded a floral duration of 3.1 days for LS flowers and 2.5 days for SS flowers for this species. Even though the values differ slightly from those recorded in the present study, it is confirmed that the LS flowers have a longer duration in comparison to the SS flower.

The period of stigmatic receptivity in this species is very long compared with other species and genera of the family, such as Paederia sp. (Puff 1991), because the stigma is receptive from the pre-anthesis stage and it remains receptive throughout the whole life of the flower. Several studies on floral biology (Coelho \& Barbosa 2004; Santos et al. 2008) realized on heterostylous species of Rubiaceae indicate that the stigmatic receptivity starts after anthesis so $O$. salzmannii is different as it has been verified that the stigma is already receptive in floral buds before anthesis.

Riveros et al. (1995) cite two species of Hymenoptera, one species of Apidae, Apis mellifera the most common visitor, one species of Halicitade and two species of Diptera (Syrphidae) as pollinators of Oldenlandia salzmannii. Even though pollination and observation of pollinators in $O$. salzmannii were not included in the aim of this study, no visits of pollinators were recorded during the observations of flowers.

\section{Self-compatibility}

As mentioned earlier, Riveros et al. (1995) demonstrated in manual experimentation that Oldenlandia salzmannii is self-compatible which means that it can self-pollinate and develop viable seeds. However, observations of the growth of the pollen tube using fluorescence microscopy should be performed in the future to extend the knowledge of the reproductive system of this species. Most of the heterostylous taxa are self-incompatible, but there are a few rare cases where heterostylous species are selfcompatible but remain morphologically distylous, for example: Amsinckia sp. (Ray \& Chisaki 1957; Ganders 1975), some species of Hedyotis sp. (Ganders 1979), etc. One of the causes of the breakdown of the self-incompatibility system in heterostylous species is that they are found in habitats where pollinators are absent or where their visits are unreliable (Ganders 1979).

Hildebrand (1886) used the term "heterostyly" for the first time in a morphological sense, without any implication as to the fertility or compatibility relationships of the plants. However, Darwin (1877) restricted the term to those species with two or more forms, that were supposed to be self-incompatible and cross-incompatible within a form, but in which pollinations between the forms were fertile (legitimate pollination). Ganders (1979) used the term "heterostyly" in a morphological sense because he believed that there are several cases of self-compatible distylous species. In conclusion, considering the previously stated evidence, this study shows that $O$. salzmannii is a distylous species in the morphological sense despite it being self-compatible.

\section{Anatomy}

No major differences between floral morphs were found in the anatomy. While vascularization of the morphs has not revealed any significant differences between the SS flowers and LS flowers, in this analysis the intimate fusion of different floral parts in the ovary was observed showing the fully receptacular inferior ovary. The general pattern of vascularization of $O$. salzmannii is very similar to that presented in some species of the Spermacoceae s. str. tribe, which were previously studied by Galati (1991).

\section{Ovule development}

The present study also examined the type and position of the ovule in O. salzmannii and ovule development was 
analyzed to provide additional information for the analysis of the evolution of embryological characters, not only for the genus but also for the family. Variations in the development and morphology of the ovule in Rubiaceae were observed by Fagerlind (1937), who differentiated different ovular types based on the number of cells of the nucellar epidermis and characteristics of archesporial cells. He proposed a diagram based on the evolution of the ovules within the Rubiaceae family; which was subsequently extended by Galati (1991), Mariath \& Coccuci (1997), and Toni \& Mariath (2008). Fagerlind (1937) distinguishes three types of nucellus for Rubiaceae: "typical", "reduced" and "naked". Genera such as Cephalanthus, Hoffmannia and Chiococca (Fagerlind 1937), present a typical nucellus. An example of naked nucellus is found in ovules of Houstonia, a close genus of Oldenlandia. Species, such as Galium palustre (Fagerlind 1937), Relbunium hypocarpium (Mariath \& Cocucci 1997) and Borreria verticillata (Toni \& Mariath 2004), present a reduced nucellus. Oldenlandia salzmannii belongs to the latter group, as the nucellus is made up only of 1-2 epidermal cells. In other African species of the genus, O. capensis and O. senegalensis, the presence of two cells in the nucellar epidermis has also been corroborated (Fagerlind 1937). As was highlighted above and from the analysis realized in this study, O. salzmannii has a reduced nucellus and presents 2-3 archesporial cells, thus this species belongs to the type of ovule described as "Oldenlandia".

Furthermore, we observed that the ovule of Oldenlandia salzmannii acquires a hemitropous position during the whole development and maturity, which represents the first record for the Spermacoceae tribe and probably for the family in which most of its representatives were described with anatropous ovules (Robbrecht 1998). In the HedyotisOldenlandia complex, there are very few embryological studies. Shivaramaiah \& Rajan (1972) studied the embryology of one species in the complex, O. umbellate, and defined the ovule as hemianatropous. In the Spermacoceae tribe, Galati (1991) analyzed the largest number of species (17 taxa), and affirmed the anatropous position of ovules from early stages of development. Subsequent studies in the tribe have recorded variations of that character: for example in Borreria palustris (Cabaña Fader 2013) and Borreria verticillata (Toni \& Mariath 2004), because the ovules present hemitropous positioning in the early stages acquiring the final anatropous position at the mature stage. On the other hand, Vijaya \& Lakshmanan (1979) described ovules of the type amphitropous for Borreria stricta.

In conclusion, Oldenlandia salzmannii is a typically heterostylous species from the morphological point of view. The anatomical descriptions, the vascularization and ovule development analysis constitute an original contribution as this species had never been studied previously from those points of views, especially the anatomical descriptions, since there are very few or no studies in the genus Oldenlandia and particularly in the Spermacoceae tribe.

\section{Acknowledgements}

We thank Sandra Martin for assistance with the statistical analyses. We appreciate the help of our colleagues Roberto Salas, Elsa Cabral, Laila Miguel, Sandra Sobrado, Javier Florentin, Marina Judkevich, Florencia Romero for their assistance in different aspects of the realization of this work. We thank the National Interuniversity Council (CIN) for the undergraduate scholarship "Scholarship Encouraging Scientific Vocations" (2014-2015), for the first author. This work was supported by PICTO-UNNE grant [N¹99/2011] and SECYT-UNNE PI [Nº12F013].

\section{References}

Andersson L, Rova JHE. 1999. The rps16 intron and the phylogeny of the Rubioideae (Rubiaceae). Plant Systematics and Evolution 214: 161-186. Bacigalupo NM. 1999. Rubiaceae. In: Correa MN. (ed.). Flora Patagónica. Colección Científica Instituto Nacional Tecnológico Agropecuario 8: 423-443.

Bahadur B. 1968. Heterostyly in Rubiaceae: A review. Journal of Osmania University. (Sci.) Golden Jubilee Special Vol. 207-238.

Bremer B. 1996. Phylogenetic studies within the Rubiaceae and relationships to other families based on molecular data. Opera Botanica Belgica 7: 33-50.

Cabaña Fader A. 2013. Análisis biosistemático del género Diodia sens. lat. (Spermacoceae, Rubiaceae). PhD Thesis, Universidad Nacional del Nordeste, Argentina.

Cabral EL. 2009. Revisión sinóptica de Galianthe subgen. Galianthe (Rubiaceae: Spermacoceae), con una sección nueva. Annals of the Missouri Botanical Garden 96: 27-60.

Castro CC, Araujo AC. 2004. Distyly and sequential pollinators of Psychotria nuda (Rubiaceae) in the Atlantic rain forest, Brazil. Plant Systematics and Evolution 244: 131-139.

Coelho CP, Barbosa AAA. 2004. Biologia reprodutiva de Psychotria poeppigiana Mull. Arg. (Rubiaceae) em mata de galeria. Acta Botanica Brasilica18: 481-489.

Consolaro H, Toledo RDP, Ferreguti RL, Hay J, Oliveira PE. 2009. Distilia e homostilia em espécies de Palicourea Aubl. (Rubiaceae) do Cerrado do Brasil Central. Revista Brasileira de Botânica 32: 677-689.

Cruden RW. 1977. Pollen-ovule ratios: A conservative indicator of breeding systems in flowering plants. Evolution 31: 32-46.

Dafni A, Maués MM. 1998. A rapid and simple procedure to determine stigma receptivity. Sex Plant Reproduction 11: 177-180.

Darwin C. 1877. The different forms of flowers on plants of the same species. London, John Murray.

Delprete PG. 2010. Rubiaceae-Parte 2: Gêneros I-R. In: Rizzo JA. (ed.) Flora dos estados de Goiás e Tocantins. Vol. 40. Goiânia, IRD/UFG. p. 710-720.

Delprete PG, Smith LB, Klein R M. 2005. Rubiáceas. Géneros de H-T. In: Reiss A. (ed.) Flora Ilustrada Catarinense. Vol. II. Itajaí, Herbário Barbosa Rodrigues. p. 486-501.

Dessein S. 2003. Systematic studies in the Spermacoceae (Rubiaceae). $\mathrm{PhD}$ Thesis, Catholic University of Leuven, Belgium.

Dessein S, Ochoterena H, Block P, et al. 2005. Palynological characters and their phylogenetic signal in Rubiaceae. Botanical Review 71: 354-414.

Dulberger R. 1974. Structural dimorphism of stigmatic papillae in distylous Linum species. American Journal of Botany 61: 238-243.

Dulberger R. 1992. Floral polymorphisms and their functional significance in the heterostylous syndrome. In: Barret SCH. (ed.) Evolution and function of heterostyly. Berlin, Springer-Verlag. p. 41-77.

Erdtman G. 1966. Pollen morphology and plant taxonomy. Angiosperms. An introduction to Palynology. I. New York and London, Hafner Publishing Company. 


\section{Morpho-anatomical and morphometric studies of the floral structures of the distylous Oldenlandia salzmannii (Rubiaceae)}

Fagerlind F. 1937. Embryologische, zytologische und bestäubungs experimentelle Studien in der Familie Rubiaceae nebst Bemerkungen über einige Polyploiditäts probleme. Acta Horti Bergiani 2: 196-470.

Faivre AE, McDade LA. 2001. Population-level variation in the expression of heterostyty in three species of Rubiaceae: Does reciprocal placement of anthers and stigmas characterize heterosyly? American Journal of Botany 88: 841-853.

Fosberg FR, Terrell EE. 1985. A recently established exotic in west Florida and Alabama (Hedyotis salzmannii or Oldenlandia salzmannii Rubiaceae). Castanea 50: 49-51.

Galati BG. 1991. Estudios embriológicos en la tribu Spermacoceae (Rubiaceae). Parte I: Anatomía Floral, Megasporogénesis, Megagametogénesis. Boletín de la Sociedad Argentina de Botánica 27: 7-20.

Ganders FR. 1975. Mating patterns in self-incompatible distylous populations of Amsinckia (Boraginaceae). Canadian Journal of Botany 53: 773-779.

Ganders FR. 1979. The biology of heterostyly. New Zealand Journal of Botany 17: 607- 635.

Gonzalez AM, Cristóbal CL. 1997. Anatomía y ontogenia de semillas de Helicteres lhotzkyana (Sterculiaceae). Bonplandia 9: 287-294.

Guo X, Wang RJ, Simmons MP, But PPH, Yu J. 2013. Phylogeny of the Asian Hedyotis-Oldenlandia complex (Spermacoceae, Rubiaceae): Evidence for high levels of polyphyly and the parallel evolution of diplophragmous capsules. Molecular Phylogenetics and Evolution 67: $110-122$

Hernández A, Ornelas JF. 2003. Correlación morfo-específica en flores de Palicourea padifolia (Rubiaceae). Boletín de la Sociedad Botánica de México 73: 35-34.

Hildebrand F. 1886. Ueber den trimorphismus in det gattung Oxalis. Monatsberichte der Königlichen Preussische Akademie des Wissenschaften zu Berlin 1866: 152-274.

Huysmans S, Robbrecht E, Smets E. 1998. A collapsed tribe revisited: Pollen morphology of the Isertieae (Cinchonoideae-Rubiaceae). Review of Palaeobotany and Palynology 104: 85-113.

Johansen DA. 1940. Plant Microtechnique. New York, McGraw-Hill Book Company.

Keller B, Thomson J, Conti E. 2014. Heterostyly promotes disassortative pollination and reduces sexual interference in Darwin's primroses. Functional Ecology 28: 1413-1425.

Koch AK, Campos da Silva P, Silva CA. 2010. Biologia reprodutiva de Psychotria carthagenensis (Rubiaceae), espécie distílica de fragmento florestal de mata ciliar, Centro-Oeste do Brasil. Rodriguésia 61: 551558.

Lewis WH. 1964. Oldenlandia corymbosa (Rubiaceae). Grana 5: 330-341.

Lewis WH. 1965. Cytopalynological study of African Hedyotideae (Rubiaceae). Annals of the Missouri Botanical Garden 52: 182-211.

Luque R, Sousa HC, Kraus JE. 1996. Métodos de coloração de Roeser (1972) - modificado - e Kropp (1972) visando a substituição do azul de astra por azul de alcião 8 GS ou 8 GX. Acta Botanica Brasilica 10: 199-212.

Maio FR. 1996. Revisão taxonomica de genero Hindsia Bentham (Rubiaceae, Hedyotideae). Archivos do Jardim Botanico do Rio de Janeiro 34: 51-92.

Mariath JEA, Cocucci AE. 1997. The ovules of Relbunium hypocarpium in the context of the Rubiaceae. Kurtziana 25: 141-150.

Massinga PH, Johnson SD, Harder LD. 2005. Heteromorphic incompatibility and efficiency of pollination in two distylous Pentanisia species (Rubiaceae). Annals of Botany 95: 389-399.
Neupane S, Dessein S, Motley TJ. 2009. The Hedyotis-Oldenlandia-Kohautia complex (Rubiaceae) in Nepal: A study of fruit, seed and pollen characters and their taxonomic significance. Edinburgh Journal of Botany 66: 371-390.

Neupane S, Dessein S, Wikström N, et al. 2015. The Hedyotis-Oldenlandia complex (Rubiaceae: Spermacoceae) in Asia and the Pacific: Phylogeny revisited with new generic delimitations. Taxon 64: 299-322.

Pire SM, Cabral EL. 1992. El valor del polen en la revalidación de Galianthe (Spermacoceae-Rubiaceae). Darwiniana 31: 1-10.

Puff C. 1991. The genus Paederia L. a multidisciplinary study. Opera Botanica Belgica 3: 195-204.

Rasband WS. 1997-2016. ImageJ, U. S. Bethesda, National Institutes of Health. http://imagej.nih.gov/ij/.

Ray PM, Chisaki HF. 1957. Studies of Amsinckia. I. A synopsis of the genus, with a study of heterostyly in it. American Journal of Botany 44: 529-536.

Richards JH, Barrett SCH. 1992. The development of heterostyly. In: Barrett SCH. (ed.) Evolution and function of heterostyly. Berlin, Springer Heidelberg. p.85-127.

Riveros MG, Barria RO, Humaña PAM. 1995. Self-compatibility in distylous Hedyotis salzmannii (Rubiaceae). Plant Systematics and Evolution 194: 1-8.

Robbrecht E. 1998. Tropical woody Rubiaceae. Opera Botanica Belgica 1: 1-271.

Santos ODA, Webber AC, Costa FRC. 2008. Biologia reprodutiva de Psychotria spectabilis Steyrm. e Palicourea cf.virens (Poepp \& Endl.) Standl. (Rubiaceae) em uma floresta tropical úmida na região de Manaus, AM, Brasil. Acta Botanica Brasilica 22: 275-285.

Shivaramaiah G, Rajan SS. 1972. A contribution to the embriology of Oldenlandia umbellata Linn. Proceedings of the Indian Academy of Sciences. Section B, Biological Sciences 77: 19-24.

Sobrevila C, Ramirez N, Enrech NX. 1983. Reproductive biology of Palicourea fendleri and P. petiolaris (Rubiaceae) heterostylous shrubs of a tropical cloud forest in Venezuela Biotropica 15: 161-169.

Stratton DA. 1989. Longevity of individual flowers in a Costa Rican cloud forest: ecological correlates and phylogenetic constraints. Biotropica 21: 308-318

Terrell EE. 1990. Synopsis of Oldenlandia (Rubiaceae) in the United States. Phytologia 68: 125-133.

Terrell EE, Robinson H. 2006. Taxonomy of North American species of Oldenlandia (Rubiaceae). SIDA, Contributions to Botany 22: 305 -329.

Toni KLG, Mariath, JEA. 2004. Desenvolvimento do rudimento seminal em Borreria verticillata (L.) G. Mey. (Rubiaceae-Rubioideae-Spermacoceae). Revista Brasileira de Botânica 27: 185-192.

Toni KLG, Mariath JEA. 2008. Ovule ontogeny in Rubiaceae (Juss.): Chomelia obtusa (Cinchonoideae-Guettardeae) and Ixora coccinea (Ixoroideae-Ixoreae). Plant Systematics and Evolution 272: 39-48.

Vaes E, Vrijdaghs A, Smets EF, Desein S. 2006. Elaborate petals in Australian Spermacoce (Rubiaceae) species: morphology, ontogeny and function. Annals of Botany 98: 1167-1178.

Vijaya V, Lakshmanan KK. 1979. Embryological studies in the Rubiaceae. II. Borreria stricta K. Schum. Journal of Madras University, Section B 42: 26-34.

Webb CJ, Lloyd DG. 1986. The avoidance of interference between the presentation of pollen and stigmas in angiosperms II Herkogamy. New Zealand Journal of Botany 24: 163-178. 